\title{
Policy Recommendations for the Planning of Multi- Level Redevelopment and Social Housing Practices
}

İmge Akçakaya Waite*

\begin{abstract}
Considering the urgent need for intervention in areas affected by problems such as gecekondu settlement and earthquake risk, redevelopment is inevitable in Istanbul. Such interventions, however, have proven problematic in meeting the local community's needs. There is a gap between the Istanbul experience and Western-in particular Western European-redevelopment practices, after which the Turkish experience has been modelled. The study aims to fill this gap through a review of these practices, a close examination of the hands-on redevelopment experience, and the lessons derived from two pioneering redevelopment projects in Istanbul: the gecekondu renewal of AyazmaTepeüstü and the earthquake-based regeneration in Sümer. 26 in-depth interviews were carried out with actors who influenced redevelopment decisions and those who were influenced by them. Data triangulation was employed to compare the two cases and reveal conflicting opinions and claims. Based on insights from informed practitioners (i.e. central government and metropolitan-level housing providers, local municipalities, and NGOs) and residents, the article analyzes the physical, financial, and community aspects of local redevelopment
\end{abstract}

Keywords: Urban redevelopment, social housing, policy development, istanbul

*Lecturer at Urban and Regional Planning Department, Istanbul Technical University ORCID

E-mail: imgeawaite@itu.edu.tr 
projects. It then derives policy sets for the planning of multi-level redevelopment and social housing practices as suggested by the project practitioners and community. This study argues that whether focused on renewal, regeneration, transformation, slum removal, or earthquake preparedness, redevelopment activities should pursue planning policies at both the general and local levels when designing a project and take into consideration the affected community's inclusion and wellbeing in corresponding policies, including those of social housing.

\section{INTRODUCTION: CONCEPTUAL APPROACHES TO REDEVELOPMENT}

Urban planning models to better existing urban areas have had many different labels: renewal, redevelopment, regeneration, recovery, revitalization, transformation, gentrification, and restructuring. In the United States (US), the term redevelopmentor in some cases, renewal-is currently more dominant, while in Western Europe regeneration is commonly the preferred term. In Turkey, the words dönüşüm, translated as transformation or regeneration, and yenileme, which more closely corresponds to renewal and less to redevelopment, are used more or less interchangeably. This is not only the case in Turkey; as happens for many concepts derived from multiple disciplines and subdisciplines, there is a lack of uniform definitions or strict boundaries for redevelopment, despite considerable attempts to establish them (Longa, 2011; Sutton, 2008; Roberts \& Sykes, 2000).

Sutton (2008) emphasizes helpful distinctions in the motives of these initiatives: whether they are people- or place-centered, and whether they are used as means or ends. She suggests that employing people as a means in pursuit of a specific goal implies the alteration of behavioral patterns, while using place as a means refers to physically changing the built environment. From an outcome-focused perspective, treating people as the ends indicates an emphasis on improved livelihoods and quality of life; this is development in the broad sense. Treating place as an end is effectively a subset of growth in the economic sense of increasing property values and returns on investment (Shihata, 1997). In this paper, the general term redevelopment is used to address the people-centered concerns embedded in regeneration and renewal practices.

This study argues that no matter they are called, redevelopment activities should pursue planning policies at both the general and local levels when designing a project and take into consideration the affected community's inclusion and wellbeing in corresponding policies, including those of social housing. The 
study makes this argument through an examination of two pioneering Turkish cases. In the following section, the paper looks at the Western traditions of redevelopment with a particular focus on Western Europe, which Turkish redevelopment history predominantly follows. The third section examines the context in Turkey and Istanbul, taking into account both past and future redevelopment agendas. The empirical research, which is introduced in the fourth section and analyzed in the fifth section, is focused on two redevelopment cases in Istanbul: AyazmaTepeüstü, located within the former borders of the Küçükçekmece district, and Sümer in the Zeytinburnu district. The pioneering nature of these cases originates from the fact that AyazmaTepeüstü was the first large-scale gecekondu redevelopment project undertaken in Istanbul by TOKI, and the Sümer Neighborhood case was the first earthquake-focused urban redevelopment project in Istanbul. The aim of the empirical research is to derive policy sets for the planning of multi-level redevelopment and social housing practices, as suggested by the project practitioners and community. These policy sets are delivered in the sixth section in three sub-sections: general redevelopment, local redevelopment, and social housing planning. Finally, the conclusion section highlights that, by taking into account such policies, it will be possible to strive for an integration of the physical, financial, and inclusionary aspects of a project for a more democratic and sustainable redevelopment scheme.

\section{REDEVELOPMENT TRADITIONS IN THE WESTERN WORLD}

The initiation of urban renewal in the US relies on a rather vague term: the appearance of "blight" in an area (Sutton, 2008; Gordon, 2003). As a result of this ambiguity, a number of interpretations of this term have been adopted by different municipal entities. For example, the New York State General Municipal Redevelopment Law defines a "blighted area" as "an area within a municipality in which one or more of the following conditions exist: (i) a predominance of buildings and structures which are deteriorated or unfit or unsafe for use or occupancy; or (ii) a predominance of economically unproductive lands, buildings or structures, the redevelopment of which is needed to prevent further deterioration which would jeopardize the economic wellbeing of the people" (§970-c).

The European counterpart of American renewal, or redevelopment, is urban regeneration, as mentioned above. Urban regeneration has widely been accepted by Western European planners as the transformation of a place (residential, commercial, or open space) that has displayed the symptoms of 
physical, social and/or economic "decline" (Evans, 2005). According to the Sydney, Australia-based International Federation of Arts Councils and Culture Agencies, regeneration is a response to decline or degeneration and can be described as the renewal, revival, revitalization or transformation of a place or community (IFACCA, 2006). Robert and Sykes (2000) elaborate on the practice further, arguing that it comprises economic issues (job prospects, employment to combat social deprivation), physical improvements, environmental preservation or restoration, and social issues (neighborhood strategies, community issues, education and training).

Urban redevelopment has a longstanding tradition in Europe. In the immediate period after World War II, the repair of wartime damage and reconstruction of the fabric of towns and cities, which in many had been neglected for years, initially took priority (Roberts, 2000). This process of reconstruction was seen as a task of national-even international-importance across the continent. Consequently, the emphasis in the 1940s and 1950s centered on reconstruction, replacement, and the eradication of the physical problems of war-torn cities. As Couch (1990) states, the government-led priorities of slum clearance and reconstruction, enthusiastically supported by local authorities and the private sector alike, led to the embrace of high-rise housing and industrialized building techniques. However, by the mid-1960s growing dissatisfaction with slum clearance and the resultant decanting of populations to peripheral estates, together with a more participatory and decentralized approach to government, led to a series of adjustments to policy informed by the growing influence of private investment and a greater balance between the public and private sectors (Roberts, 2000). In the urban policy field this change in priorities resulted in an increased emphasis on improvement and renewal. This 'discovery' of the city, together with the first uncertain steps towards the generation of urban policy, led to a major expansion of urban initiatives during the 1970s (Turok, 1987). The result of this increase in initiatives was a series of attempts to improve coordination between the previously separate economic, social, and physical notions of policy.

Many of the urban policy initiatives of the 1970s, which involved peripheral renewal with a local spatial focus triggered by private investments, initially continued into the 1980s, although substantial modifications and additions were subsequently introduced (Turok, 1987). During the 1980s there was a move away from the idea that the central state should or could provide all of the resources necessary to support policy interventions. This 
new policy stance in Europe was matched by a greater emphasis on the role of partnerships. Roberts (2000) states that the more commercial style of urban redevelopment evident in the 1980s reflected yet another set of changes in the nature and structure of political philosophy and control. The redevelopment of flagship projects through private investment reduced the role of the public sector more than ever before, to merely that of a facilitator that provided selective public funds as well as very selective state support in a social context that mainly emphasized community self-help.

Further adjustments to the form and execution of urban policy occurred in the 1990s, with a return to a more consensus-driven style of politics and the recognition of a series of new problems and challenges (Vickery, 2007). National policy statements on 'design' in urban regeneration were stronger, placing design matters at the center of urban and economic planning (DOE, 1997; DETR, 2000). The prospect of integrating design, cultural activities, and urban regeneration gave rise to an emphasis on heritage, preservation, and the role of community. This trend continued into the 2000s, with an added emphasis on sustainability (Leary \& McCarthy, 2013).

These economic, physical, and social ambitions, with their attendant weaknesses, can also be observed in the Turkish redevelopment agenda. In Turkey, the general components of redevelopment are apparent in project publicity reports as rationales, and as observed in the empirical research of this study, accompanied by local justifications such as earthquake threat, illegal settlements, and excessive population and building densities, all of which result in safety concerns (Gül \& Dulupçu, 2010; Ezme, 2017). However, even though current projects are defined as a form of urban redevelopment, due to the lack of coordination of redevelopment components and their ignorance concerning present social structures and potential future social conflicts, the concept of redevelopment in Turkey deviates to an extent from today's Western notions and experiences (Güzey, 2013; Kuyucu, 2018).

\section{TOWARDS LOCALITY: AGENDA SHIFTS IN TURKEY AND ISTANBUL}

Municipalities in Turkey have for more than 150 years been organizers of urban development in the modern sense (Ersoy, 2001). Today, the Turkish territorial hierarchy for urban planning, from large to small scale, is ülke (country), il (province), ilçe (district), and mahalle (neighborhood). Although the current 
Turkish Zoning Law (No. 3194) specifies different types of development plans at different levels and scales, the most widely used at the city level are "physical development plans" and "implementation plans," which are used in the planning and execution of redevelopment projects.

The roots of urban redevelopment activities in Turkey are found in the gecekondu (squatter) settlements that emerged in major Turkish cities in the early 1950s (Tas \& Lightfoot, 2005). As in post-war Europe, policies of economic growth and industrialization motivated the rapid growth of urban centers and the development of gecekondu in large cities in Turkey. By the 1970s, municipal governments regarded gecekondu areas as the source of all negative externalities in large cities, and municipal agencies regarded their demolition and subsequent public housing applications as the only solution (Güzey, 2013). This policy of demolition resulted in the eviction of gecekondu populations in central urban areas. Although not mentioned in plans, the replacement of a lower-income population with a higher-income group-in other words, gentrification-was an expected and deliberate underlying purpose of redevelopment (Uzun, 2003; Güzey, 2009). Hence redevelopment plans, shaped by physical redevelopment projects prior to the 1970s, aimed at improving highly dense and irregular housing areas, and redevelopment was treated as a means of increasing housing stock.

The year 1980 was a turning point for Turkey in many respects. After a military coup on September 12, the central government implemented neoliberal economic policies and structural adjustments to integrate Turkey into international markets and embrace the dynamics of the free market economy (Kazgan, 1997; Özdemir, 2011). In the 1980s, two important developments in the urban space attracted attention: an increase in the construction of both authorized residential areas and gecekondu, and the decentralization of residential areas. Urban redevelopment within this period took place in inner city residential and industrial areas, central business districts, and coastal areas (Egercioğlu \& Özdemir, 2007).

Since coming to power in November 2002, the Islamic and conservative Justice and Development Party (Adalet ve Kalkınma Partisi - AKP) has encouraged the consolidation of neoliberal spatial policies. Bakçay-Çolak (2012) iterates that the resulting new model of urban management has transformed the city's main functions for the purpose of generating urban income and distributing this income arbitrarily to give birth to a new, 
conservative bourgeoisie, particularly in Istanbul. The Housing Development Administration of Turkey (Toplu Konut ÍdaresiTOKI) emerged as another factor central to the urban restructuring process in this period (www.toki.gov.tr). Established in 1984 under the Prime Ministry to help ameliorate the housing problems of middle and lower-middle income groups, TOKI became an active investor in mass housing, equipped with special powers and financial resources to accomplish vast urban transformation projects through joint ventures with private developers and local municipalities (Türk \& Korthals Altes, 2014; Aksoy, 2012). This model is reflected at the municipal level in a subsidiary of the Istanbul Metropolitan Municipality (IMM), the Istanbul Housing Development Organization Co. (İstanbul Konut İmar Plan Sanayi ve Ticaret A.Ş. — KIPTAŞ).

Despite considerable attempts to balance out the impacts mentioned above through community inclusion and participation related to urban redevelopment practices in Turkey (Varol, Ercoşkun \& Gürer, 2011; Karaman, 2014), overall, the new legal framework and the neoliberalization process have had a number of consequences in major cities in Turkey, particularly in Istanbul. Bartu-Candan and Kolluoğlu's (2008) assessment provides a summary of these consequences:

- A new neoliberal language that involves abundant usage of the terms vision, mission, transparency, efficiency, accountability, and public participation;

- A dramatic shift in the type of private investments, marked by a spectacular increase in the number of hotels, shopping malls, and office buildings since the 1980s;

- A change in the actors of the real estate market, e.g. the emergence of real estate investment trusts and TOKI, introduced by legislative interventions of the central government; and

- The emergence of the discourse of natural disasters following the 1999 Marmara earthquakes, which emphasizes strengthening housing stock for an anticipated highmagnitude earthquake in Istanbul.

In Istanbul, an additional significant motive for the transformation of the city was its repositioning as a 'global' city, in competition with with the leading metropolitan cities of the world (Aksoy, 2012; Uzun, 2003). In the case of housing provision, the abovementioned consequences and motives are reflected in urban redevelopment projects either as mega-projects designed by world-renowned architects (e.g. the Kartal project by Zaha Hadid and the Küçükçekmece project by Ken Yeang) or as 
gecekondu transformation projects. Accordingly, applications in Turkey have been directed mostly at residential contexts, especially gecekondu, and used as tools in the re-acquisition of rent in cities' most appealing locations (central areas, development sites, and the like) and in the creation of highincome and high-status housing (Güzey, 2009).

As a final analysis of the urban redevelopment processes in Turkey, it is necessary to mention a more recent development in the legislative arena. Due to the central government's increasing ambitions regarding redevelopment and its need to further control project initiation, the Turkish Parliament passed the first law to directly address urban development on May 16, 2012: law no. 6306 on the "Redevelopment of Areas under Disaster Risk," more commonly called "the Urban Redevelopment Law." It aims at "determining procedures and principles regarding the rehabilitation and renewal of lands under disaster risk or plots with buildings under disaster risks in order to provide healthy and safe living environments" (Official Journal, 31 May 2012). Since its initiation, a number of amendments have been made to the law to ameliorate the ill consequences it has had on redevelopment practices (Balaban, 2019). Due to the ongoing restructuring of this law and the overall time frame of this study, which was conducted from 2014-16,, the case projects examined in this paper were undertaken under previous laws. Nevertheless, implications derived from the empirical research can inform possible consequences of the Urban Redevelopment Law.

\section{NOTES ON EMPIRICAL METHODOLOGY}

The empirical study examines published and unpublished material in addition to collecting and analyzing primary data through qualitative methods. Primary data collection was conducted through in-depth interviews in one-on-one sessions with a total of 26 informed subjects from two case projects. These interviews aimed at revealing project decisions and the rationales behind them, and at determining policy proposals based on the redevelopment practice of these projects, as perceived by the actor groups. The subjects thus comprised local municipalities at district level (The Municipality of Küçükçekmece, Istanbul一the $M K I$ - and the Municipality of Zeytinburnu, Istanbul-the MZI), governmental development institutions (TOKİ and KIPTAŞ), NGOs (the Urbanism Movement of Society, Istanbul-imece-and the Migrants' Association for Social Cooperation-Göç-Der in the Ayazma-Tepeüstü case-and the Association of the Istanbul Zeytinburnu Curtain Manufacturers Market-ISPER in the Sümer case), and the community representatives of different user types 
(owner or tenant, status groups, and ethnicities, where applicable). In addition to interviews via a snowball sampling method that covered all actors willing to participate (Noy, 2008), the qualitative research involved participant observation with an ethnographic approach (O'Reilly, 2012). In order to ensure the confidentiality of the subjects, any descriptive information has been omitted except for contextually vital institutional names and positions. Triangulation of coded data (Lewis \& Ritchie, 2003) allowed comparison within and between different categories of actors of each project (triangulation of sources) as well as comparison of the two projects (environmental triangulation).

\section{COMPARATIVE REVIEW OF CASES: AYAZMA-TEPEÜSTÜ AND SÜMER}

Küçükçekmece and Zeytinburnu were among the districts in Istanbul for which there was a need for large-scale rehabilitation and revitalization of gecekondu sites and increased preparedness for an expected major Istanbul earthquake (Erdik \& Durukal, 2008). Both cases are the primary examples of their kind in Istanbul and Turkey. The Ayazma-Tepeüstü case (2004-2012) was the first large-scale gecekondu redevelopment project undertaken with TOKİ, while the Sümer case (first phase in 20082013) presented the first earthquake focused in situ urban redevelopment project to be realized in a high-density settlement.

\section{Site selection and characteristics}

Ayazma and Tepeüstü were determined through field and community surveys conducted by the MKI in 2004 to be two of the four most problematic gecekondu neighborhoods of Küçükçekmece (Ramazanoğulları Turgut \& Çaçtaş Ceylan, 2012). As reported by the MKI and TOKI interviewees, their selection over other neighborhoods was mainly due to their location, land ownership pattern, lack of urban facilities, pedestrian access problems, and poor public health conditions around the river bed, which also posed a flood threat. The problems of the Sümer neighborhood were rooted in larger scale issues that affected the whole Zeytinburnu district. As an MZI official elaborated, Zeytinburnu's earthquake risks are significant due to its problematic high-density building stock, which was constructed without consideration for the area's hazardous geology and poor urban conditions, which include unplanned development, inadequate social facilities, a lack of open spaces, narrow roads, and urban poverty. In both cases, locational advantages were mentioned multiple times by almost all interviewees (Figures 1 and 2). Ayazma and Tepeüstü are valuable neighborhoods, easily visible from surrounding major developments, adjacent to main 
highway arteries and junctions that connect the sites to the Atatürk International Airport and the nearby Atatürk Olympic Stadium, which was envisioned as a major focus of mega-event planning in Istanbul, an aspect of the ambitious "world city" vision of the government for Istanbul. The Sümer neighborhood is also close to a main highway and the Ataturk Airport and is easily accessible from important transport routes such as the Marmaray tunnel, the Kabataş-Zeytinburnu light rail, and the Kazlıçeşme International Seaport.

Figure 1. Ayazma, Tepeüstü, Bezirganbahçe, and other important land uses within the former Küçükçekmece district border (Produced by author)

Figure 2. The Sümer Neighborhood within the Zeytinburnu district borders (Produced by author)
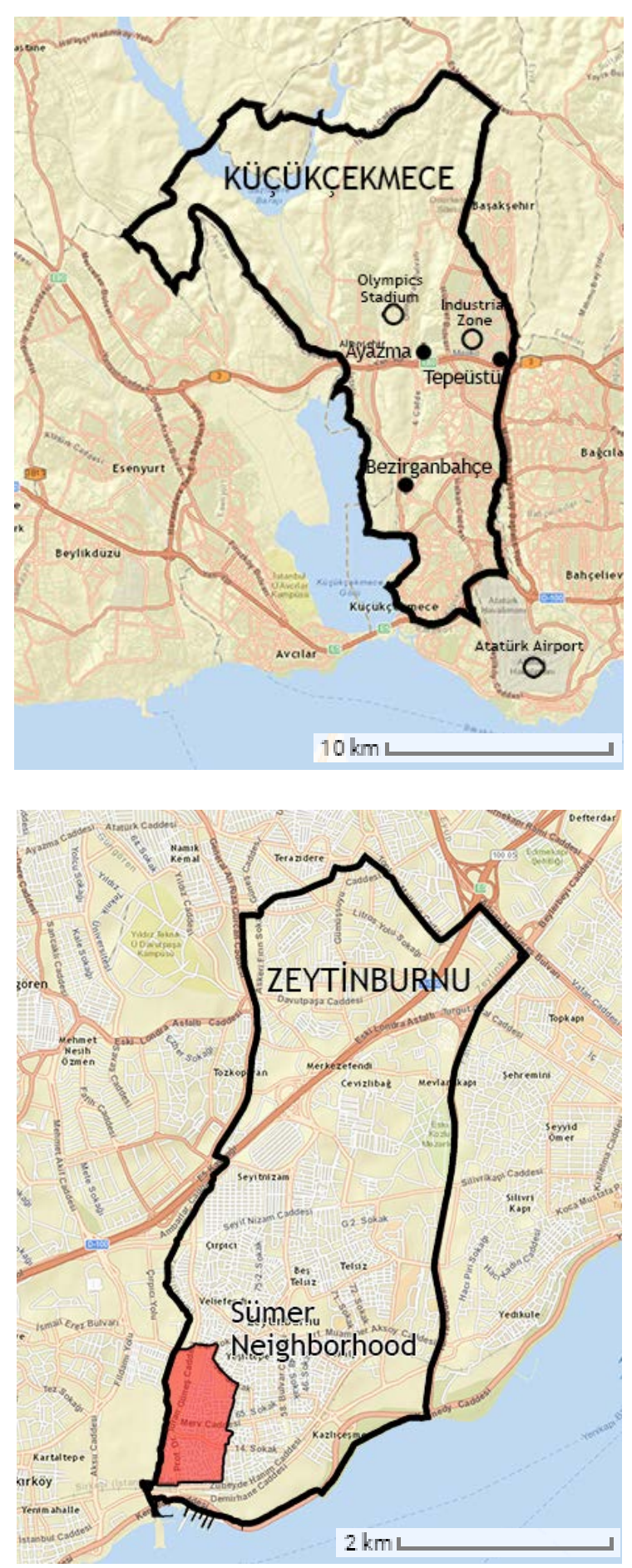
Issues of land and unit ownership were especially problematic in both cases because of their heavy gecekondu presence. MZI and TOKİ officials reported that while land ownership in the Sümer neighborhood was roughly $90 \%$ private, around $40 \%$ of Ayazma and $80 \%$ of Tepeüstü were developed on State Treasury land. Almost all pre-existing Ayazma and Tepeüstü units and 35\% of Sümer units were illegally built, which prompted the government to call some of their residents "illegal occupiers," particularly in the Ayazma-Tepeüstü case.

Ayazma was a hub of socio-economic disadvantages: the community was plagued by very low education and income levels and high unemployment, both of which contributed to poor living conditions in both Ayazma and Tepeüstü (Ramazanoğulları Turgut \& Çaçtaş Ceylan, 2012). Sümer residents had comparatively higher education levels than residents of AyazmaTepeüstü (around 85\% were primary school graduates, according to one resident) and higher paying jobs on average, either through blue-collar work or small businesses they operated in Zeytinburnu. The community surveys conducted by the local municipalities in both cases determined that the communities were unable to partake in redevelopment activity at their own expense due to their low income levels. On a final note, as MKI and community representatives stated, while the population of Tepeüstü was mostly heterogeneous, the majority of the Ayazma population were Kurds who had emigrated from eastern Turkey. Both MKI and NGO representatives mentioned the history of political tensions between this group and the AKP government because of the latter's conservative and nationalist stance; in fact, this tension was a significant source of the community conflicts in the Ayazma-Tepeüstü case (also see Uzunçarşılı Baysal, 2013).

\section{Project formulation: Physical and financial aspects}

The earlier project alternatives for Ayazma-Tepeüstü and Sümer had different stances on community needs and displacement than the projects' eventual outcomes. The MKI's first zoning plan and design study foresaw on-site public housing for existing Ayazma residents and a public convention center in Tepeüstü; however, these measures were replaced by TOKI's plans, which displaced the residents and offered an uplift of the area as elaborated below. In Sümer's case, following three declined project alternatives proposing a shopping mall and luxury high-rise condos on site, the KIPTAŞ-MZI project partnership had to generate an in situ solution due to public reaction against displacement.

In the fourth project alternative, which was eventually implemented in Sümer, project executives decided to use a nearby 
1.4 ha state-owned soccer field to construct Sahilpark, a securitycontrolled gated housing site with street-facing stores, transfer the 3,600 residents from 1,038 units and 212 retail stores to the new units, and build the second phase on the 4.9 ha lot they vacated (Figure 3). The project also called for the concurrent development of a nearby 10.6 ha private lot to build a new sports facility and luxury housing project, The Istanbul, to generate income for the development of Sahilpark. The Sahilpark housing site was also an uplift: it offered a 25 sqm parking space to each unit in an underground parking structure, a leisure area by an ornamental pool, a playground, and an exercise station.

Figure 3. Components of the Sümer urban redevelopment project area (Produced by author)

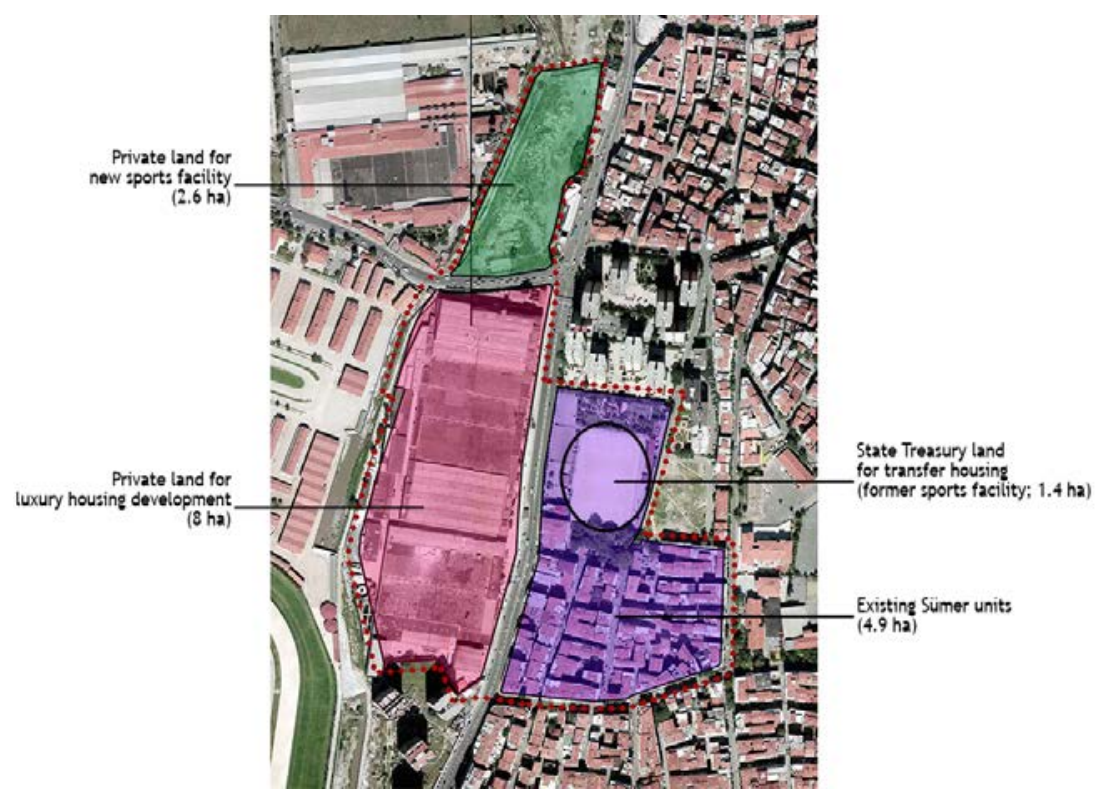

The flat-for-land method was used once the rightful owners agreed to partake in the project. KIPTAŞ staff conducted a gross unit measurement study for each existing unit, which reportedly caused friction among residents due to the intangible qualities of their homes. In determining the allocation of new units, KIPTAS decided on a $25 \%$ deduction of the existing unit area in order to compensate the project costs. MZI and KIPTAŞ officials considered this rate a major incentive to the community in a metropolis like Istanbul, where, they claimed, the average rate was $50 \%$. After application of the deduction, a Sahilpark unit that corresponded to the deserved value was offered. In order to compensate any size differences, and in accordance with the fair property value analysis they undertook, KIPTAŞ and the MZI set the equalization price for unit area at TRY 2,500 per sqm for Sahilpark units, with the existing units valued from TRY 700 to 1,000 per sqm. An ISPER representative explained that a similar set of deals was formulated for the store owners of the project area, but a business taxation problem arising from a lack of proper legal remedies 
hindered them from signing project agreements over the course of the first phase of the project.

The anonymity of some interviews helped reveal a hidden financial agenda in the Sümer case. It was claimed that the private lot's owner, the Koç Group, was the actor that profited most from the project: its former afforestation property was now zoned for housing and designated for the eventual development of The Istanbul, $40 \%$ of which was allocated to the group. One official also predicted the construction of approximately 3,500 units to replace the 1,250 existing units of Sümer by the end of the second phase, and argued that some portion of the remaining units would be delivered to KIPTAŞ as profit based on a $40 \%$ flat-for-land method.

In the Ayazma-Tepeüstü case, the TOKİ and MKI officials reported that the redevelopment project sites in Ayazma and Tepeüstü were 20 ha and 13 ha, respectively, housing a total of approximately 8,800 residents in 2,070 units in 700 buildings, collectively. These officials co-decided to construct a public housing site where the gecekondu residents would be transferred in a less accessible Bezirganbahçe location that originally belonged to the State Treasury to make room for development that could take advantage of the favorable location and high value of the original land. Later, in order to address the demand of some Ayazma homeowners who wanted to stay in their neighborhood, TOKİ built a few housing blocks in Çakmak, which was closer to Ayazma. The rightful owners were asked to choose to what area they wanted to be transferred (Figure 4).

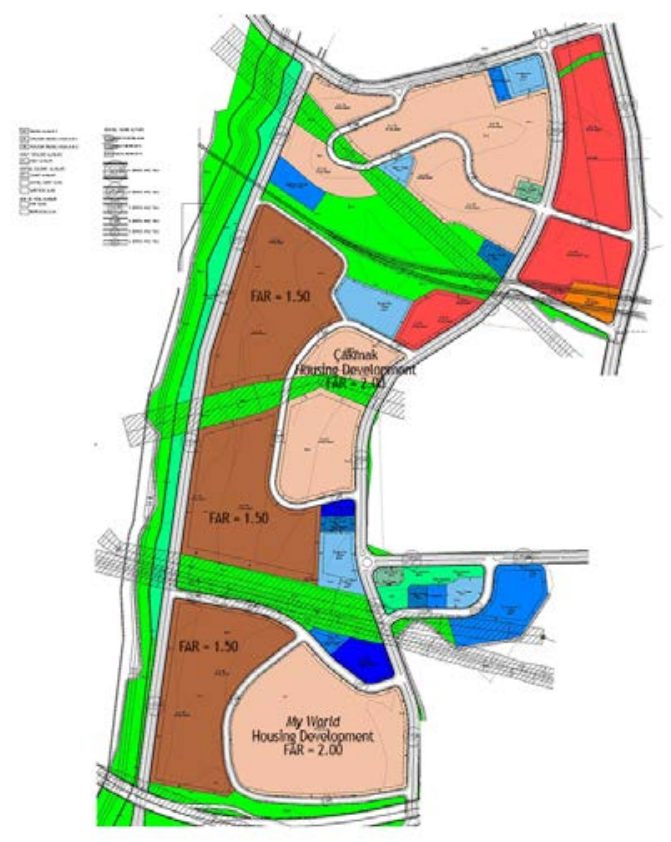

Figure 4. TOKI's 1:1000 plan for the extended Ayazma site dated 2008 (Adapted from the image by TOKI Istanbul Redevelopment Office archive, April 2014) 
TOKİ later sold the former Ayazma and Tepeüstü lots at auction through its Property and Housing Real Estate Investment Company. The Ağaoğlu Group purchased the Ayazma site to build the luxury housing project My World, while the Torunlar Group purchased Tepeüstü as land zoned for retail and tourism with an increased building density and built a high-end mixed-use complex, the Mall of Istanbul, with offices, luxury condominiums, and a shopping mall. TOKI partnered in both developments. In all development projects, actual construction was outsourced to private firms that used their own workforce and inspected by the employer institutions, which proved to be insufficient to maintain construction quality and safety, as admitted by the TOKI executives interviewed.

The financial terms offered to Ayazma-Tepeüstü residents were relatively simple compared to those offered to Sümer residents. The rightful owners of Tepeüstü, all of whom owned gecekondu on state property, received one Bezirganbahçe unit in exchange for every unit they owned. As financier of the public housing project and a non-profit developer, TOKI determined the dwelling unit price in Bezirganbahçe to be TRY 51,000 based on land, construction, and project costs. It appraised each gecekondu unit on state-owned land in Ayazma at a flat price of TRY 10,000 regardless of its size, condition, or location, an amount that was considered a down payment toward the Bezirganbahçe units. The remaining balance was termed for 15 years of fixed interest-free installments. Upon the objections of the Ayazma residents due to financial hardship, then-Prime Minister Erdoğan used his right of initiative in favor of the community and announced a $10 \%$ discount. If residents agreed to pay the unit price in advance, they were offered an additional $20 \%$ discount. Nevertheless, although its officials did not make financial details explicit, residents and NGOs claimed that TOKI gained substantial profit from the publicprivate partnership projects realized in Ayazma and Tepeüstü.

As is apparent above, in both case projects, the rightful owners were offered a seemingly limited flexibility regarding the units they could choose to receive. However, with little to no room for negotiation, if they did not agree with the project terms, they were forcibly excluded from the project through legal means, which favored the government. There were numerous claims of apathy, bullying, despotism, unfair allegations, and neglect, which caused multiple conflicts between the government and the community in the Ayazma-Tepeüstü and Sümer projects. 
Policy Recommendations for Planning of

Multi-level Redevelopment and Social Housing Practices

\section{Community Inclusion: Government and Resident Perspectives}

In both cases, the majority of the interviewees from the government institutions and all of the interviewed rightful owners stated that the community was not adequately involved in the project's direct decision-making, while all interviewees reported that the level of formal public participation was "information giving" at the most. According to a TOKI manager, community surveys were a means of formal participation, while interviewees from Imece and Göç-Der argued that the surveys were by design one-way instruments tailored to gather information about residents rather than enable a two-way discussion that might facilitate collective decision-making. As for Sümer, the MZI vice mayor pointed to the simultaneity of the decision-making process and the collection of the community's opinion in the early stages of the project: the decision-makers made a decision, then communicated it with the rightful owners via presentations and models. He stated that the project partnership used this method to obtain the community's verbal consent for the ultimate decision to implement the redevelopment project.

An MZI planning officer pointed to the general lack of legal regulation concerning formal participation methods in urban planning in Turkey, an absence which resulted in neither the MZI nor KIPTAŞ applying any further methods, such as co-discussing and co-deciding on design alternatives or receiving the rightful owners' written consent. While this officer agreed on the inadequacy of Turkish legislation, an Imece representative offered a different approach to the participation mechanism. She believed that revolving participation meetings and public persuasion processes were unnecessary if the community clearly did not want to realize a project or wished to remain in their area: in the Ayazma-Tepeüstü case, for instance, the community's desires and needs were so explicit that there was "no need of such democratic charades."

The government's positive attempt to elevate the education level and general quality of life of the local community was spearheaded in the Ayazma-Tepeüstü case when the project consultant, also a planning professor, founded a social empowerment project, Bizim Halka, and established a project office that employed sociology, psychology, and preschool education professionals to ease the residents' adaptation to mass housing life in Bezirganbahçe (Ramazanoğulları Turgut \& Çaçtaş Ceylan, 2012). However, interviewed residents argued that the program was terminated because of a number of challenges 
involving project operations, effectiveness, and lack of community trust. In the Sümer case, such an empowerment program was not considered, possibly because the new lifestyle in Sahilpark was more welcomed by the residents who were able to stay in their neighborhood and whose socio-economic status was on average higher than that of Ayazma residents.

The most significant and resonant community resistance of the two redevelopment projects was that of the tenants of Ayazma (Bartu-Candan \& Kolluoğlu, 2008; Aksoy, 2012; Uzunçarşşlı Baysal, 2013; "Ecumenopolis", 2012). In interviews, officials from TOKI and the MKI defined the protestors as "marginal groups," alluding to their partial Kurdish identity. The MKI vice mayor believed that the fact that the residents did not sufficiently know how to seek their rights diminished their potential influence over decisions. In Sümer, an officer and an anonymous interviewee of the MZI asserted that for the most part, household visits and informal resident meetings were conducted one-on-one to prevent any group "synergy" or opposition. As claimed by multiple interviewees, with this and other project marketing and persuasion strategies, the MZI-KIPTAŞ partnership was largely successful in its attempts to divide the community.

\section{INFORMED POLICY SETS FOR REDEVELOPMENT AND SOCIAL HOUSING PROGRAMS}

In both cases, interviewed officials suggested a connection between the novelty of the projects and explained how they derived lessons for further redevelopment activities in Istanbul. The practice-oriented lessons in this section offered by the redevelopment practitioners are translated into three sets of policies for redevelopment at the general level, at the local level, and relating to social housing, with insights for more democratic and sustainable outcomes (Table 1). 
Policy Recommendations for Planning of

Multi-level Redevelopment and Social Housing Practices

Table 1. Practice-oriented policies suggested by the informed practitioners

\begin{tabular}{|c|c|}
\hline Planning type & Informed policies \\
\hline $\begin{array}{l}\text { General } \\
\text { redevelopment }\end{array}$ & $\begin{array}{l}\text { - Steering the national economy to address housing problems } \\
\text { Planning at the national, regional and metropolitan levels } \\
\text { - Holistic approach: all departments, all sectors, all needs } \\
\text { - Long-term and longitudinal planning } \\
\text { - Dartnership with the community } \\
\text { being of residents } \\
\text { - Prioritization of in situ social housing over gentrification } \\
\text { - Abandonment of the "sign or leave" attitude }\end{array}$ \\
\hline $\begin{array}{l}\text { Local } \\
\text { redevelopment }\end{array}$ & $\begin{array}{l}\text { Longer-term and election-free planning } \\
\text { - Consideration of idiosyncratic conditions } \\
\text { - Pre-project determination of local needs and interests } \\
\text { - Generation of multiple community-friendly scenarios } \\
\text { - Encouragement of area-based redevelopment } \\
\text { - Building density control and amenities } \\
\text { - } \text { Aalue-based assessment of existing units } \\
\end{array}$ \\
\hline Social housing & $\begin{array}{l}\text { Depot housing concept } \\
\text { - Modest and secure living spaces for higher quality of life } \\
\text { - Adequate and maintained community amenities and } \\
\text { infrastructure } \\
\text { - Production of jobs and employment } \\
\text { - Construction quality management } \\
\text { - Moderately high buildings at lower building density } \\
\text { - Various unit types to combat "choicelessness" } \\
\text { - Rental and sale options and affordability } \\
\end{array}$ \\
\hline
\end{tabular}

\section{General Redevelopment Planning}

Steering the national economy toward addressing housing problems. A high-rank TOKİ executive proposed that the national economy should be steered toward the production of more feasible housing options for citizens, while financially empowering the state to realize public housing projects and build earthquake-resilient urban areas. A crucial note offered by an activist suggested that the state's earthquake relief taxes collected from the citizens since the early 2000s should be spent on their intended purpose of disaster mitigation instead of on unrelated purposes such as highway construction. Likewise, a portion of gentrification revenues could be transferred to public housing projects to increase their building quality and the quality of life they provide.

Planning at the national, regional and metropolitan levels. Government officials from both case studies believed that their projects lacked a holistic approach to redevelopment, which integrated all past, current, and future redevelopment activities in Istanbul. Redevelopment planning should be carried out at national, regional, and metropolitan scales, with local redevelopment projects generated accordingly. Large-scale planning should project population movement, transportation infrastructure, project phasing, and financial alternatives to inform local practices. 
Holistic approach: all departments, all sectors, all needs. In addition to master redevelopment planning, the executives of TOKİ suggested undertaking a more multi-disciplinary approach, with the inclusion of historians, sociologists, psychologists, economists, tourism professionals, and investors along with planners, architects, and cartographers to ensure more sustainable and viable outcomes from redevelopment practices. Another TOKİ officer emphasized the government's role in such collaboration and argued that central and local governments should adopt a more active role in guiding and monitoring the collaboration of various parties, in particular regarding compliance with the law. He added that leading central government institutions, such as the Ministry of the Environment and Urbanism and the legislators of Urban Redevelopment Law No. 6306, should be involved in redevelopment discussions. After all, the burden of solving redevelopment problems did not lay with the citizens; it was the responsibility of government officials at all levels to seek out workable housing strategies to promote their citizens' happiness.

Long-term and longitudinal planning. In reference to following up local residents' lives after displacement, an MKI planning executive likened her institution's treatment of the AyazmaTepeüstü redevelopment to child abandonment, although she believed that it was not the planning department's but academia's job to conduct follow-up social programs or data collection studies. As a scholar, the municipality's redevelopment consultant also emphasized the necessity of longitudinal studies and offered various research topics based on her experience and observations at Bezirganbahçe: the increase in crime rates and the profile of organized crime, residents' social interactions and sense of security, and changes in former Ayazma women's lifestyles. Former Ayazma residents now living in Bezirganbahçe seconded these concerns.

Partnership with the community. Because of the dominant focus on the collaboration of formal actors, few subjects brought up the need for the active involvement of the local community in project decision-making. In line with general participation practices in Istanbul and Turkey, the government informed the public of the details of the implemented redevelopment process only after having consulted all higher government entities and received their approval. A government official admitted that the formal redevelopment actors, including TOKİ, carried out planning decisions on a two-dimensional platform (physical and financial planning) and dismissed the third social dimension. If TOKI and the local municipality had included this third dimension, he 
argued, the problems of social and financial adaptation to a new high-rise lifestyle could easily have been foreseen.

Development of programs for the social and economic wellbeing of residents. A municipality advisor argued that housing provision was not enough to sustain public happiness; public housing policies had to work hand in hand with other social programs to combat large-scale unemployment and education problems in these low-income populations. One simply could not achieve this at the municipal level without a deep change in the understanding of governance on a national scale. He suggested that the government should initiate programs for the socioeconomic well-being of residents that go hand-in-hand with those promoting awareness in order to effectively involve communities in decision-making.

Prioritization of in situ social housing over gentrification. NGO activists asserted that this prioritization is essential in acknowledging low-income illegal settlements and their communities' desires. Redevelopment projects should aim to solve long-established housing problems in metropolitan cities such as Istanbul while keeping the willing population on site. An advocacy planner objected to the need for displacement, arguing that it should not be an automatic policy for redevelopment but an agenda only if local residents are not willing to live in their neighborhood or if the geological condition of land does not allow for any kind of development, suggesting that where the occupied land already belongs to the state, the government can adopt in situ public housing policies to legally accommodate local residents and other communities in need. Such in situ formulations would free the government from the burden of expropriation and allow it to retain ownership of centrally located state lands.

Abandonment of the "sign or leave" attitude. According to some government officials, a powerful central government was necessary to assure the successful realization of redevelopment projects in Turkey. Behind this assumption is the opinion, one official argued, that unlike in Europe, where redevelopment is understood as painting and planting around an industrial plant, redevelopment in Turkey-as in all developing countries-is defined as the total removal of building(s) or function(s) and that the central government should thus have significant economic and legal power to initiate, plan, and execute projects. A KIPTAŞ executive further argued that using forceful tactics was an inevitability in societies like Turkey; the government had to "hold the stick" in order to persuade its people and accomplish its projects where citizens refused to compromise. Others had a more 
community-friendly stance. They believed that redevelopment was a necessary and inevitable physical intervention measure to solve the rooted housing problems of Istanbul, but that municipalities had to offer the residents more agreement options than a mere "sign or leave."

\section{Local redevelopment planning}

Longer-term and election-free planning. Local government executives stressed the importance of changing the timespan of redevelopment projects, arguing that projects should be allowed at least 10 years (instead of 5 years, which is the interval between local government elections), freeing public actors of election concerns in order to allow for a more thorough project formulation and implementation.

Consideration of idiosyncratic conditions. Multiple interviewees emphasized the uniqueness of each redevelopment project in its physical, economic, and social conditions, differences that any collaboration should consider carefully when tailoring project formulations while also adopting broader redevelopment guidelines and policies. As the NGO representatives suggested, employing survey methods to assess residents' sincere opinions and demands is also necessary for determining the distinctive conditions of the community.

Pre-project determination of local needs and interests. When considering communities' needs and interests, some subjects from both government and non-government institutions envisioned a set of tools to collect residents' sincere opinions and demands before the project formulation phase, so that formal institutions could make more public-friendly decisions. A parallel suggestion was that zoning and local redevelopment plans should call for community consent and participation before project initiation.

Generation of multiple community-friendly scenarios. In both cases, the community rejected the project options the formal actors suggested because they were not realistic or communityfriendly enough and oriented more toward profit for the government and private stakeholders. An MKI officer suggested that redevelopment project partnerships should instead focus on developing alternative scenarios with local communities and other stakeholder groups: plans should be generated to allow some residents to stay on site, some to be compensated for the property they are willing to vacate, and some to be offered public housing elsewhere. 
Encouragement of area-based redevelopment. The local municipality officials argued that planning guidelines should promote block-based rather than lot-based redevelopment, as redevelopment in larger lots tends to yield greater benefits for the community (i.e. by allowing for more orderly building clusters and the elimination of parking problems). For instance, in the Zeytinburnu case, the MZI had recently attached a note to the 1:5000 zoning plan for Zeytinburnu to the effect that the residents of a building block were at that time encouraged to gather and agree on redevelopment via a 15\% increase in construction area in areas of at least $1000 \mathrm{sqm}$. The 1:1000 implementation plans were being prepared in line with this 1:5000 plan report.

Building density control and amenities. In both cases, as in almost all cases in Istanbul, building density was increased considerably via redevelopment. A KIPTAŞ executive admitted that the idea of redevelopment through density increase was developed by the government prior to and independent of the disaster risks. Although he believed that securing the lives of the Zeytinburnu residents was the project's foremost objective, the means by which the redevelopment was carried out, e.g. the zoning change on Koç land and the increase in population density and resulting traffic congestion, were not exactly compatible with this end. A TOKI executive seconded this criticism and added that if TOKİ were to plan the Ayazma-Tepeüstü redevelopment project over again, it would look for ways to lower density further than what has been realized in the original neighborhoods and better organize urban facilities to provide a more balanced and sufficient social infrastructure. These officials believed that as an alternative to deducting from existing unit area and increasing density to compensate for project costs, a financial formulation that embraces a one-for-one principle with increased unit prices while keeping residents on site and maintaining the same density may be encouraged. Such an approach would not require low project costs and construction quality and would allow for the design of parking spaces and recreational amenities, perhaps with higher standards.

Value-based assessment of existing units. One problem in the Ayazma-Tepeüstü case involved the assessment of the units of local residents that ignored intangible qualities (i.e. floor, view, orientation, building quality, etc.). A KIPTAŞ official observed that, as opposed to taking into account merely the size of a unit, a valuebased method was more precise in assessing a unit's intangible qualities and could yield faster and fairer results by preventing conflicts. 
Affordability. There were conflicting implications regarding different affordability segments within the community. In the Sümer case, a major finding of the initial community survey indicated a low-income profile. However, the MZI vice mayor claimed that residents claimed a higher ability to pay when they saw the value increase in the new development, Sahilpark. Those who could afford new Sahilpark units demanded more or larger units from the government, so a KIPTAŞ executive suggested that instead of a $25 \%$ deduction rate per unit, the financial formulation for future redevelopment projects should be made on a one-forone principle with increased unit prices while at the same time keeping residents on site and retaining the area's original building density. He referred to such a process as "producing quality work despite the citizens," as he believed that it was impossible to satisfy all residents anyway.

\section{Social Housing Planning}

Depot housing concept. The Ayazma-Tepeüstü project's municipality consultant suggested that public housing be built in suitable locations (often in peripheral areas) and made available to local communities for long-term housing in times of redevelopment. In accordance with central or metropolitan-level policies, the government can make pre-built public housing sites available to homeowners or tenants to prevent them from having to move to other illegal or disaster-prone areas.

Modest and secure living spaces for higher quality of life. In general, residents called for social housing projects to fulfill two major community-friendly criteria: affordability and livability. Community advocates argued that while public housing projects need not be luxurious like My World in Ayazma, they should offer high quality of life, meaning that the safety of the community should be prioritized at a cost that is within the reach of residents, and that the government's overall priority should be to ensure the betterment and security of the lives of those now living in public housing.

Adequate and maintained community amenities and infrastructure. Residents also demanded that social housing projects should offer better-organized and sufficient public amenities such as playgrounds, social facilities, schools, and health clinics. A local municipality official recalled her immense efforts to appeal to the Istanbul Metropolitan Municipality for outdoor cleaning at the Bezirganbahçe public housing site; however, as a mere local municipality officer, her voice was not heard. The upkeep of the housing site was abandoned shortly after the project's completion, as this officer and the residents claimed 
that the private site management company employed by TOKİ did an inadequate job. In particular, if development must be carried out at the less valuable periphery of the city to reduce land costs, she argued that the government might offer decent services in more distant areas (i.e. improved transportation connections, better community amenities, and higher construction quality).

Production of jobs and employment. A local activist asserted regarding the Ayazma-Tepeüstü case that the health and employment problems of low-income communities surpassed their housing problems; she therefore called for government programs that foster nearby employment opportunities to ensure citizens' socio-economic wellbeing and allow them to work in jobs that would normally exclude them from government assistance. On the other hand, a TOKI official suggested that $95 \%$ of the residents wanted to stay in their neighborhood in urban redevelopment schemes and that everyone demanded at least a one-for-one formulation, if not more. In order to come to a compromise with the residents, he argued, the government should offer livable and appealing low-cost public housing projects with employment opportunities on less valuable land outside the city centers, providing larger units and jobs to ensure the citizens' socio-economic wellbeing.

Construction quality management. TOKİ officials acknowledged the inadequate workmanship at Bezirganbahçe but placed blame squarely on the contractors, even though TOKİ undertook quality management and inspection of construction activities. They argued that when looking for ways to reduce unit costs, the government should take measures (e.g. personnel training) that will increase the effectiveness of inspections of the contractors' work to prevent them from reducing construction costs at the expense of quality.

Moderately high buildings at lower building density. A former local municipality executive criticized TOKI for the excessive increase in building density in both Ayazma and Tepeüstü. The population had to move from their (1-2 story) low-rise homes to 10-to-15-story buildings. A TOKI executive admitted that TOKI "confined the people to high-rises" for the sake of cost-effective construction. The forced change in the lifestyle of former Ayazma residents caused severe reported adaptation problems (e.g. lack of yards, children falling from balconies). Thus, lower building density and moderate building height should be top priorities in social housing projects. 
Various unit types to combat "choicelessness." TOKİ used only one unit type for all family sizes and lifestyles to ensure low construction costs. This approach allowed social housing units to be offered to residents at a low price, although sites like Bezirganbahçe resulted in the abovementioned social and physical costs. All TOKI officials interviewed argued that the urgent need for low-cost public housing developments was almost over, as the majority of low-income people were provided with public housing in Turkey and the market had reached a balance. It was now time to generate more unit types in lower-height buildings to increase the quality of life of their inhabitants.

Rental and sale options and affordability. Because it was difficult for the low-income residents of both cases to afford new unit loans, the community activists argued that the government should seek financial formulations in which public housing units could be for either rent or sale or could be given at no cost to the residents but without transfer of ownership.

\section{CONCLUSION: ROOM FOR FURTHER (RE)DEVELOPMENT}

The arguments and suggestions offered by the informed practitioners of the case projects are parallel to those offered in the Western literature. Overall, they call for a comprehensive and urgent transformation of redevelopment policies, as the current applications fail to fulfill the community's needs while deeply affecting their lives. The findings also suggest that the legacy of redevelopment depends on a successful social housing program, in the absence of which the redevelopment efforts may bring severely ill consequences. As European practitioners and policymakers realized in the 1960s and 1970s, coordination between the previously distinct economic, social, and physical notions of policy should be improved in Istanbul and in Turkey. Otherwise, growing dissatisfaction with place-centered redevelopment decisions, gecekondu clearance, and the resultant displacement of populations to peripheral and undesirable estates observed in post-World War II Europe will prevail. What distinguishes applications in Turkey from the models in developed countries is the tendency to regard urban redevelopment as a form of projectbased housing supply rather than as a holistic restructuring process that should be evaluated at a larger scale. A set of keys offered in the literature can be summarized in Robert and Sykes' (2000) list of the components of urban redevelopment programs: the identification of problems, constraints, opportunities, resource requirements, and overall strategy accompanied by a detailed schedule of implementation and action in the framework of partnership and sustainability. A set of keys specific to the 
Istanbul experience discussed in this study can shed light on current attempts at the reformulation of the redevelopment scheme in Turkey and elsewhere.

There are a number of specific potential applications inspired by the case projects of this study. Some interesting topics that merit further exploration include the ways in which the urban identity of Istanbul perceived by the government and how its inhabitants have affected the form, appearance, and aspirations of redevelopment projects; the changing concept of the mahalle in today's Istanbul as a major factor in defining area-based redevelopment sites; the role of the press as an important participant in redevelopment debates; social influences beyond the oblique associations inherent in references to the Kurds; the impact of the 5-year local election cycle on redevelopment projects; and the ultimate housing outcomes of redevelopment projects for different kinds of gecekondu households (i.e. owners, tenants, households with small homes, others with larger homes). The sustainability of quality of life is as important as its establishment; therefore, academics should be encouraged to conduct longitudinal post-occupancy research about residents affected by redevelopment. The study of practice in the face of the complex relations of power, political loyalties, and ethnic, religious and territorial identities (and more) should extend to the micro-political details of planning practices. Further conceptualization and generalization of case findings may help academics see some of what can be learned from practice and help them to gear their instruction to the realities of practice.

\section{REFERENCES}

Aksoy, A. (2012). Riding the storm: 'new Istanbul.' City: analysis of urban trends, culture, theory, policy, action, 16(1-2), 93111.

Bakçay-Çolak, E. (2012). Istanbul, a rebelling city under construction, Housing in Europe: Time to evict the crisis, 7 , 34-40.

Balaban, M. S.. (2019). Hazard-prone cities and recent challenges in the case of urban transformation experience of Turkey. In Ö. B. Özdemir Sarı, S. Özdemir \& N. Uzun (Eds.), Urban and regional planning in Turkey (pp. 235-259). Springer, Cham.

Bartu-Candan, A., \& Kolluoğlu, B. (2008). Emerging spaces of neoliberalism: A gated town and a public housing project in Istanbul, New perspectives on Turkey, 39, 5-46.

Couch, C. (1990). Urban renewal theory and practice. Basingstroke, UK: MacMillan.

DETR (Department of Environment, Transport and the Regions). (2000). Our towns and cities-the future: Delivering an urban Renaissance. London: DETR/Stationery Office. 
DOE (Department of Environment). (1997). Planning policy guidance: General policy and principles (Report No. PPG1). London: DOE/Stationery Office.

Ecumenopolis. (2012). Ecumenopolis: City without limits. Documentary written and directed by İmre Azem. Retrieved from https://www.youtube.com/watch?v=maE cPKBXV0M.

Egercioğlu, Y., \& Özdemir, S. (2007). Changing dynamics of urban transformation process in Turkey: Izmir and Ankara cases. In Proceedings of the 47 th International congress of the European Regional Science Association, Paris, France, 29 August-2 September, 1, 254-256.

Erdik, M., \& Durukal, E. (2008). Earthquake risks and its mitigation in Istanbul, Natural Hazards, 44(2), 181-197.

Ersoy, M. (2001). Democratization through de-centralization? The Turkish case. Paper presented in the 1 st World Planning Schools Congress, Shanghai, China, July.

Evans, G. (2005). Measure for measure: Evaluating the evidence of culture's contribution to regeneration, Urban Studies, 42(5), 959-983.

Ezme, A. T. (2017). A Reading of Gecekondu as a Tool of Rapid Urbanization and Cheap Economic Development. In S. Çelik, 0. Küçükahmetoğlu \& J. Dobreva (Eds.), Contemporary Studies in Social, Economic \& Financial Analysis (pp. 63-86). London: IJOPEC Publication Limited.

Gordon, C. (2003). Blighting the way: Urban renewal, economic development, and the elusive definition of blight. Fordham Urban Law Journal, 31, 305-337.

Gül, H., \& Dulupçu, M. A. (2010). Local Economic Development, Urban Change and Regeneration in Turkey: Possibilities for Transcending Beyond Modernism. In J. Diamond, J. Liddle, A. Southern \& P. Osei (Eds.), Urban Regeneration Management: International Perspectives (pp. 168-185). Routledge.

Güzey, Ö. (2009). Urban regeneration and increased competitive power: Ankara in an era of globalization, Cities, 26, 27-37.

Güzey, Ö. (2013). Evaluation of urban regeneration as a government-assisted revenue strategy in Turkey: the global imperative. In M. Leary \& J. McCarthy (Eds.). The Routledge Companion to Urban Regeneration (pp. 86-96). Oxon: Routledge.

IFACCA (International Federation of Arts Councils and Culture Agencies). (2006). Arts and culture in regeneration (D'Art report No. 25). Sydney: IFACCA.

Karaman, O. (2014). Resisting urban renewal in Istanbul. Urban Geography, 35(2), 290-310.

Kazgan, G. (1997). Küreselleşme ve yeni ekonomik düzen [Globalization and the new economic order]. Istanbul: Altın Kitaplar.

Kuyucu, T. (2018). Politics of Urban Regeneration in Turkey: Possibilities and Limits of Municipal Regeneration Initiatives in a Highly Centralized Country. Urban Geography, 39(8), 1152-1176. 
Leary, M., \& McCarthy, J. (2013). Conclusions and aspirations for the future of urban regeneration. In M. Leary \& J. McCarthy (Eds.). The Routledge Companion to Urban Regeneration (pp. 569-584). Oxon: Routledge.

Lewis, J., \& Ritchie, J. (2003). Generalising from qualitative research. In J. Ritchie \& J. McCarthy (Eds.). Qualitative research practice: A guide for social science students and researchers (pp. 263-286). London: Sage Publications.

Longa, R. D. (2011). Urban Models. In R. D. Longa (Ed.). Urban Models and Public-Private Partnership (pp. 7-46). Heidelberg: Springer.

Noy, C. (2008). Sampling knowledge: The hermeneutics of snowball sampling in qualitative research. International Journal of social research methodology, 11(4), 327-344.

O'Reilly, K. (2012). Ethnographic methods. Routledge.

Özdemir, D. (2011). The role of the public sector in the provision of housing supply in Turkey, 1950-2009. International Journal of Urban and Regional Research, 35(6), 1099-1117.

Ramazanoğulları Turgut, S., \& Çaçtaş Ceylan, E. (2012). In the wake of a local government initiative: Istanbul - Küçükçekmece Urban Regeneration Project. Southampton, UK: WIT Press.

Roberts, P. (2000). The evolution, definition and purpose of urban regeneration. In P. Roberts \& H. Sykes (Eds.). Urban Regeneration A Handbook (pp. 9-36). Sage Publications.

Roberts, P., \& Sykes, H. (2000). Introduction. In P. Roberts \& H. Sykes (Eds.). Urban Regeneration A Handbook (pp. 3-8). Sage Publications.

Shihata, I. F. (1997). Democracy and development. International \& Comparative Law Quarterly, 46(3), 635-643.

Sutton, S. (2008). Urban revitalization in the United States: Policies and practices. Final Report: United States Urban Revitalization Research Project (USURRP). Submitted to Seoul National University.

Tas, H. I., \& Lightfoot, D. R. (2005). Gecekondu settlements in Turkey: Rural-urban migration in the developing European periphery. Journal of Geography, 104(6), 263271.

TOKİ (Toplu Konut İdaresi Başkanlığı). (2019, July 31). Background. Retrieved from https://www.toki.gov.tr/en/ background.html.

Türk, Ş. Ş., \& Korthals Altes, W. K. (2014). The applicability of inclusionary housing (IH) in Turkey. Journal of Housing and the Built Environment, 29(3), 507-520.

Turok, I. (1987). Local economic development in post-war Britain: Processes, policies and their evaluation. London: Avebury.

Uzun, C. N. (2003). The impact of urban renewal and gentrification on urban fabric: three cases in Turkey. Tijdschrift voor economische en sociale geografie, 94(3), 363-375.

Uzunçarşılı Baysal, C. (2013). Civilizing the Kurdish population of Ayazma: Ayazma/Tepeüstü urban transformation project-Küçükçekmece, Istanbul. Planning, 23(2), 83-94.

Varol, C., Ercoşkun, O. Y., \& Gürer, N. (2011). Local participatory mechanisms and collective actions for sustainable urban development in Turkey. Habitat International, 35(1), 9-16. 
Vickery, J. (2007). The emergence of culture-led regeneration: $A$ policy concept and its discontents. West Midlands, UK: Centre for Cultural Policy Studies, University of Warwick.

\section{Resume}

Imge Akçakaya Waite, $P h D$, is a researcher and lecturer at the Department of Urban and Regional Planning at Istanbul Technical University, where she received her Bachelor's and Master's degrees. She earned her PhD at the Urban Planning Department in the Luskin School of Public Affairs at University of California, Los Angeles (UCLA), with her dissertation titled "Planning, power, politics: Urban redevelopment in Istanbul." Among her recent fields of interest are decision-making and governance mechanisms, inclusive and collaborative planning, urban planning project organization, and planning education. 